\title{
The PHOTON2 web-based professional development model: a year in review
}

Nicholas Massa, Judith Donnelly, Alexandra Bell, KelliMarie Vallieres, Fenna Hanes

Nicholas Massa, Judith Donnelly, Alexandra Bell, Kelli-Marie Vallieres, Fenna Hanes, "The PHOTON2 web-based professional development model: a year in review," Proc. SPIE 9664, Ninth International Topical Meeting on Education and Training in Optics and Photonics, 96641N (24 October 2005); doi: $10.1117 / 12.2207710$

SPIE Event: Ninth International Topical Meeting on Education and Training in Optics and Photonics, 2005, Marseille, France 
This paper is freely available as a resource for the optics and photonics education community.

\title{
Ref ETOP050
}

The PHOTON2 Web-Based Professional Development Model: A Year in Review

\author{
Nicholas Massa ${ }^{1}$, Judith Donnelly ${ }^{2}$, Alexandra Bell and Kelli-Marie Vallieres ${ }^{3}$, Fenna Hanes ${ }^{4}$ \\ ${ }^{1}$ Springfield Technical Community College, 1 Armory Square, Springfield, MA 01105 \\ massa@stcc.edu \\ ${ }^{2}$ Three Rivers Community College, 7 Mahan Drive, Norwich, CT 06030 \\ jdonnelly@trcc.ccommnet.edu \\ ${ }^{3}$ University of Connecticut, 249 Glenbrook Road, Storrs, CT 06269 \\ Sandy.bell@uconn.edu; Kelli-Marie.Vallieres@uconn.edu \\ ${ }^{4}$ New England Board of Higher Education, 45 Temple Place, Boston, MA 02111 \\ fhanes@nebhe.org
}

\section{Keywords}

Web-based, online, photonics, optics, laser, self-regulation, metacognition, professional development, collaborative, adult learning, active learning, interaction, self-efficacy, critical thinking.

\begin{abstract}
In this paper, we present preliminary results from project PHOTON2, a National Science Foundation Advanced Technology Education (ATE) project aimed at increasing the number of high school teachers and college faculty across the US prepared to teach photonics technology at their own institutions. During the Fall 2004 and Spring 2005 semesters, two cohorts (51 high school teachers and college faculty) from 12 states across the US including Hawaii participated in a web-based Introduction to Optics \& Photonics course. Qualitative and quantitative research was conducted to examine the relationship between learner interaction, self-regulation, and learning outcomes in a web-based learning environment. Research results and recommendations are presented.
\end{abstract}

\section{Introduction}

\section{Summary}

Photonics technology, defined as the practical application of light, is a broad subject that encompasses enabling electro-optical technology, devices and implementation across the STEM disciplines. In the same way that electronics changed our lives in the twentieth century, photonics will play a critical role in fields, such as manufacturing, wireless communications, medical devices and procedures, defense and space exploration, as well as consumer electronics; all crucial to our national economic leadership and security [1]. The National Committee on Optical Science and Engineering stated, "Despite its essential enabling roles - or perhaps because of it -optics remains an ill-defined educational program at most institutions" [2].

As a first step in addressing this issue, the New England Board of Higher Education, in partnership with photonics technology educators from Springfield Technical Community College and Three Rivers Community College, and adult learning experts from the University of Connecticut Neag School of Education, developed a collaborative web-based learning program to help teachers and faculty: (1) develop core competency in optics and photonics technology; 
(2) apply and adapt optics and photonics content into their own courses and curriculum; (3) develop the self-directed learning skills deemed critical to life-long learning; and (4) establish and maintain a collaborative online learning community consisting of peers, mentors, and industry professionals that support the transfer of learning through synergistic learning activities

During the Fall 2004 and Spring 2005 semesters, two cohorts consisting of a total of 51 high school teachers and college faculty from 12 states across the US began a 3-year professional development program that includes a one-semester (15-week) web-based "Introduction to Optics and Photonics" course, a two-week summer internship with a photonics company, extensive hands-on experiential learning, and ongoing technical support with curriculum development and implementation. The first cohort (Cohort 1) consisted of four regional teams or "alliances" made up of high school STEM instructors, community college technology faculty, and in some instances engineering faculty from 4-year institutions; The second cohort (Cohort 2) consisted of five alliances. Figure 1 shows a map in which the stars mark the geographic regions represented by Cohorts 1 and 2 . Each participating institution was provided with a complete set (15 chapters) of field-tested optics and photonics course content, a $\$ 4000$ custom optics lab kit that included a field-tested lab manual with over 30 experiments ranging from simple demonstrations of refraction and diffraction to building and aligning a Michelson interferometer, and two CD-ROM videos in which PHOTON2 instructors provide step-by-step instructions for performing each experiment [1].

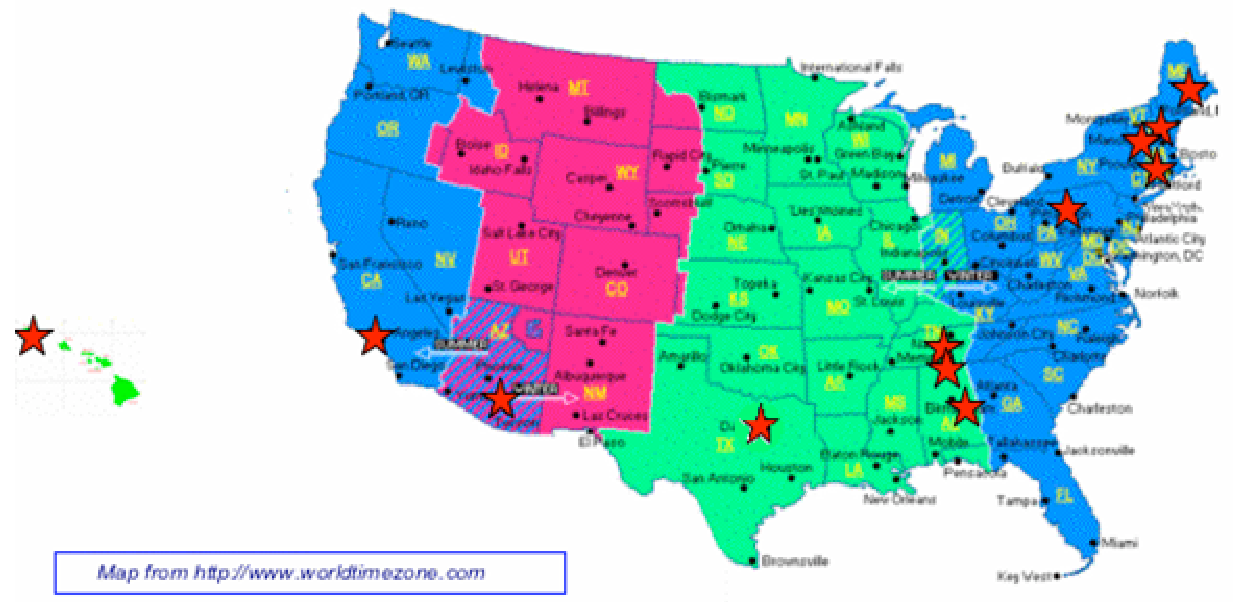

\section{Figure 1. PHOTON2 Geographic Regions}

In comparison to traditional models of professional development (e.g., short courses and workshops), the use of the Internet for delivery of educational materials, instruction and training has several advantages including the ability for learners to learn at their own pace, access information at their own convenience, and communicate asynchronously with instructors and peers $[2,3,4,5]$. Researchers $[22,23,24]$ argue that in contrast to face-to-face courses, online 
courses not only provide learners with the opportunity for extended reflection time, allowing them to compose more thoughtful and probing contributions, but also the opportunity to engage in collaborative learning with peers, instructors, and experts from around the world in a way that capitalizes on professional and common interests. In this collaborative learning model, learners work together on academic tasks and construct knowledge and ideas through interactions and responses from others. Research shows that collaborative learning results in more learner involvement with the course, more engagement in the learning process, and is more effective than traditional methods in promoting learning and achievement [6].

One of the challenges in successfully implementing a web-based professional development model, however, is getting participants to actively engage in online discussions and activities [7]. For that reason, an integral part of the PHOTON2 project involves research aimed at answering the question of why some learners succeed more readily than others in online courses. Previous work has shown that the strength of learners' self-regulation - in other words, their ability to understand their own learning processes and adjust their learning strategies accordingly, has a direct relationship to how well they perform in an online course $[8,9,10]$. Studies have also shown that individuals learn better when there is more learner interaction both instructionally and socially with instructors, peers, and course content $[11,12,13]$. In short, an online course that supports the development of self-regulation skills and provides for enhanced learner interaction in its overall design will have a positive effect on how well learners perform.

In this paper, we will discuss what we have learned about what works and what doesn't in webbased professional development from two semesters of the PHOTON2 project. In addition to providing insights on course structure, pedagogical methods, and hands-on laboratory experiences, we will examine the relationship between learner interaction, self-regulation, and learning outcomes.

\section{The PHOTON2 web-based professional development model}

The PHOTON2 web-based professional development model is grounded in the application of adult learning principles in an online learning environment. Adult learning research shows that adults learn in many different ways and are motivated by many different factors. While a number of theories, models, and frameworks have been developed over the past 30 years, there is still no single unifying theory of adult learning [1, 14,15,16,17,18,19]. Analysis of the literature on adult learning does, however, yield a certain set of learner characteristics that can be used to guide the development of professional development programs. These characteristics can be summarized in the following way:

- Autonomy: Adults prefer to work independently and with minimal supervision. They can nevertheless thrive in interdependent, connected and collaborative ways so long as their autonomy is respected.

- Experience: Adults bring a rich background of life experiences to the classroom. They learn best when new knowledge builds on this experience.

- Goal Orientation: Adults tend to be goal-oriented, participating in educational programs to fulfill specific objectives.

- Relevance: Adults prefer educational program that have relevance to their needs and interests. 
- Pragmatism: Adults seek to apply what they have learned to their real-world lives in practical ways.

- Internal Motivation: Adults tend to be motivated more by internal factors than by external factors.

The PHOTON2 program addresses these characteristics by engaging learners in an educational experience in which learning is active, continuous, coherent, and collaborative (see Figure 1) with the goal of building learners' capacity to: (1) apply and adapt both learned photonics content knowledge and learning strategies to their own courses and institution; (2) establish and maintain a collaborative learning community of photonics educators and industry professionals who support learning through synergistic learning activities; and (3) engage in lifelong learning through the development of self-regulated learning strategies.

The overarching goal of the PHOTON2 program, or any professional development project for that matter, is to improve faculty proficiency, the ability to skillfully apply knowledge in a way that significantly improves teaching and student learning. A proficient educator is one who can skillfully apply knowledge, construct and organize knowledge to address instructional, and even institutional challenges, by adapting and changing their teaching and program development strategies $[1,20,21]$. Specifically, the PHOTON2 program is designed to help teachers and faculty build a well-organized knowledge base in photonics technology as well as the ability to apply their new knowledge to develop and implement more effective instructional practices at the both classroom and the program level.

The pedagogical framework used to guide the design and facilitation of learning activities that promote the construction of knowledge and support the skilled application of new knowledge in the classroom was based on five key principles for effective adult learning adapted from Keeton, Sheckley, and Griggs [20]. These five principles, which serve as the foundation for the PHOTON2 professional development model, have as their central tenet; instruction that leads to proficiency (i.e., the skilled application of knowledge) must continuously establish the link between content and how it is skillfully applied $[1,20]$. These principles are summarized in Table 1. 


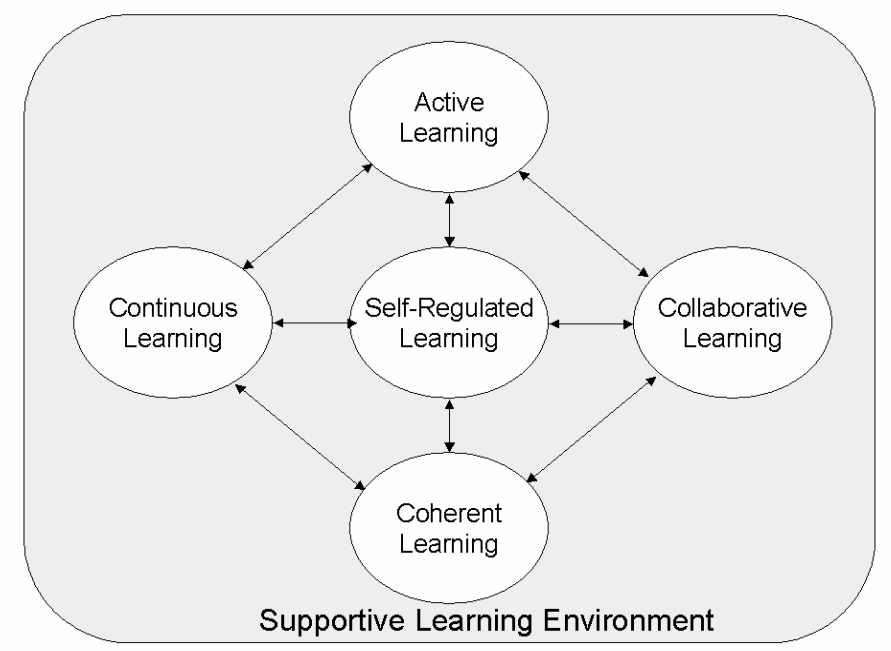

Figure 2. PHOTON2 Professional Development Model [1]

\begin{tabular}{|c|c|c|}
\hline Principle & Description & Application \\
\hline ing & $\begin{array}{l}\text { Professional development } \\
\text { must include hands-on } \\
\text { experience, reflection, } \\
\text { practice, and feedback to } \\
\text { actively engage faculty in } \\
\text { constructing, organizing, } \\
\text { and experimenting with a } \\
\text { rich knowledge base that } \\
\text { learners can successfully } \\
\text { apply to real problems of } \\
\text { teaching. }\end{array}$ & $\begin{array}{l}\text { Learners engage in experiential learning with peers } \\
\text { and instructors through solving closed and open- } \\
\text { ended photonics problems, hands-on laboratory } \\
\text { experiments, group exercises to identify } \\
\text { instructional challenges, and development of } \\
\text { instructional modules for use in the classroom. } \\
\text { Instructors promote and structure individual and } \\
\text { collaborative reflection on photonics content, } \\
\text { photonics instruction, and the learning of photonics } \\
\text { technology through threaded discussions. }\end{array}$ \\
\hline $\begin{array}{l}\text { Cor } \\
\text { Lea }\end{array}$ & $\begin{array}{l}\text { Professional development } \\
\text { must include sufficient } \\
\text { number of contact hours } \\
\text { over a span of time to } \\
\text { enhance faculty } \\
\text { processing and problem } \\
\text { solving skills. }\end{array}$ & $\begin{array}{l}\text { Learners develop proficiency in photonics through } \\
\text { continuous professional development, support, and } \\
\text { feedback over a three-year period. Participants } \\
\text { engage in coursework aimed at developing a } \\
\text { robust and retrievable knowledge base in } \\
\text { photonics-related content and apply their } \\
\text { knowledge in solving real-world problems through }\end{array}$ \\
\hline
\end{tabular}


faculty externships with their local photonics industry. By applying their knowledge in the classroom, the laboratory, in industry, and through mentoring over a continuous three-year period, PHOTON2 participants will develop the knowledge, skills, and confidence to implement photonics curricula in their own classrooms.

Professional development Parallel development of learners' Learning must be centered around the problems of teaching and program development that faculty face to allow for practice with employing new knowledge in real world contexts.

knowledge, curriculum, and self-regulatory skills. Learners develop specific lesson plans to be used with their own students in collaboration with their alliance members. Learners work on problems ranging from photonics concepts and applications, to problems associated with the teaching of photonics, to the problems associated with building regional partnerships designed to enhance education-business collaboration.

Collaborativ Learning based on the Learners are part of a regional collaborative e Learning collective participation of "alliance" or team that include high school teachers in a learning teachers, 2- and 4-year college faculty, and career community results in and guidance counselors. Learners work on group increased learner projects, share and discuss experimental results, proficiency. and collaborate on regional curriculum development issues. Learners collaborate online with instructors, industrial advisors, and mentors.

\begin{tabular}{|c|c|c|}
\hline $\begin{array}{l}\text { Self- } \\
\text { Regulated } \\
\text { Learning }\end{array}$ & $\begin{array}{l}\text { Professional development } \\
\text { programs that scaffold the } \\
\text { development of or } \\
\text { enhance learners' self- } \\
\text { regulation } \\
\text { metacognitive skills will } \\
\text { result in more proficient } \\
\text { and confident lifelong } \\
\text { learners. }\end{array}$ & $\begin{array}{l}\text { Learners articulate specific learning goals as well } \\
\text { as a route to achieving those goals. Learning } \\
\text { activities are structured in ways that help learners } \\
\text { identify and manage their individual learning } \\
\text { strengths and challenges to help improve their } \\
\text { learning success. Activities such as goal setting, } \\
\text { online self-assessments, instructor and peer } \\
\text { feedback, reflective journals, and contextual } \\
\text { learning help learners acquire the skills needed to } \\
\text { plan, monitor, and evaluate their own learning and } \\
\text { boost self-efficacy. }\end{array}$ \\
\hline
\end{tabular}

Table 1. Summary of Five Key Principles for Effective Adult Learning

\section{A. The PHOTON2 Curriculum: A Tale of Two Courses}

The PHOTON2 web-based course (Introduction to Optics and Photonics) was offered to two cohorts, Cohorts 1 and 2 respectively, during the Fall 2004 and Spring 2005 semesters. The four-credit 16-week web-based course was offered through the school of continuing education at Three Rivers Community College in Norwich, CT. Course recruitment was conducted by the New England Board of Higher Education (NEBHE) during the Spring 2004 semester. The 
course was advertised as a web-based professional development program in photonics technology education through individual solicitation, NEBHE's website (www.nebhe.org), the International Society for Optical Engineering (SPIE; www.spie.org), the Optical Society of America (OSA; www.osa.org) and through a variety of engineering technology and physics listserves. Formal application to the program required community college faculty, high school teachers, and career and guidance counselors to apply as a regional team or "alliance" to facilitate collaboration between secondary and post-secondary education. The competitive process yielded 23 participants from six regions representing institutions from New England, California, Arizona, Texas, and Pennsylvania for Cohort 1 and 28 participants from five regions representing institutions from New England, Pennsylvania, Tennessee, Alabama, California and Hawaii for Cohort 2. Table 2 provides a demographic breakdown of participants.

\begin{tabular}{|l|l|l|l|l|}
\hline \multirow{2}{*}{ Demographic } & \multicolumn{2}{l|}{ Cohort 1 (N=23) } & \multicolumn{2}{l|}{ Cohort 2 (n=28) } \\
\cline { 2 - 5 } & $\mathbf{n}$ & Percentage & $\mathbf{n}$ & Percentage \\
\hline Number of High School Teachers & 12 & 53 & 16 & 57 \\
\hline $\begin{array}{l}\text { Number of Community College } \\
\text { Faculty }\end{array}$ & 11 & 47 & 12 & 43 \\
\hline Female & 6 & & & 22 \\
\hline Male & 17 & 26 & 6 & 78 \\
\hline Highest Educational Level & & 74 & 22 & \\
\hline \multicolumn{1}{|l|}{ BS Degree } & 13 & 57 & 15 & 54 \\
\hline MS Degree & 5 & 22 & 10 & 36 \\
\hline PhD & 5 & 22 & 3 & 11 \\
\hline Never taken a web-based course & 9 & 38 & 14 & 50 \\
\hline Average number of years teaching & 9.6 & - & 11 & - \\
\hline Average age (yrs) & $40-50$ & - & $40-50$ & - \\
\hline
\end{tabular}

Table 2 - Demographic Breakdown for Cohort 1 and 2 Teachers/Faculty

Prior to each course, each regional alliance participated in a two-day introductory workshop held at one of the participating institutions to introduce participants to the online learning environment, course material and laboratory equipment, to establish a professional rapport with the PHOTON2 team and alliance participants, and to assess the learning environment at each regional site. Each of the two-day workshops also included a tour of a local photonics company in an effort to solicit industry participation in the program and to provide career and guidance counselors with career awareness in the photonics field. A partial list of companies included, Cisco Systems, Veeco Instruments, Photon Machining, Coherent Laser, Trex Enterprises, and several others.

The Introduction to Optics and Photonics web-based course was designed to provide learners with a broad overview of photonics principles and applications. The course covered principles of light and electromagnetic energy including, geometric and wave optics, basic laser principles, and fiber optics as well as optics and photonics applications. Both deductive and inductive problem solving was used to develop learners' deep understanding of core principles and critical thinking skills. Laboratory experiments, designed to reinforce concepts covered in the course, ranged from simple demonstrations of basic optical principles such as reflection and refraction to more sophisticated experiments such as diffraction gratings and interferometry. A field-tested 
laboratory manual supplemented with CD-ROM video demonstrations of each experiment provided step-by-step procedures for conducting each experiment. A list of the course material and experiments covered in the 16-week semester are provided in Table 3.

\begin{tabular}{|c|c|c|}
\hline Major Course Topics & Laboratory Experiments & \\
\hline $\begin{array}{ll}\text { - } & \text { Laser Safety } \\
\text { - } & \text { The Nature of Light } \\
\text { - } & \text { Geometric Optics } \\
\text { - } & \text { Optical Instruments } \\
\text { - } & \text { Wave Optics } \\
\text { - Introduction to Lasers } \\
\text { - Introduction to Fiber } \\
\text { Optics }\end{array}$ & $\begin{array}{l}\text { - } \quad \text { Sources of Light } \\
\text { - } \quad \text { Plane mirrors } \\
\text { - } \text { Singll's Law } \\
\text { - } \quad \text { Systems of Two Lenses } \\
\text { - } \quad \text { Laser Beam Collimation } \\
\text { - } \quad \text { Spherical mirrors } \\
\text { - } \quad \text { Moung's Double Slit } \\
\text { - Interferen Interferometer in an Air Wedge } \\
\text { - } \quad \text { Diffraction Gratings } \\
\text { - } \text { Malus' Law }\end{array}$ & $\begin{array}{ll}\text { - } & \text { Brewster's Angle } \\
\text { - } & \text { Single Slit Diffraction } \\
\text { - } & \text { Laser Range Finder } \\
\text { - } & \text { Laser Bar Code } \\
& \text { Scanner } \\
\text { - } & \text { Single Beam Reflection } \\
& \text { Hologram } \\
\text { - } & \text { Two Beam } \\
& \text { Transmission Hologram } \\
\text { - } & \text { Laser Beam Profile } \\
\text { - } & \text { Numerical aperture of a } \\
& \text { plastic fiber }\end{array}$ \\
\hline \multicolumn{3}{|l|}{ Explorations (Demonstrations) } \\
\hline $\begin{array}{ll}\text { - } & \text { Light Spectra } \\
\text { - } & \text { Pinhole Camera Viewer } \\
\text { - } & \text { Reflection }\end{array}$ & $\begin{array}{ll}\text { - } & \text { Refraction } \\
\text { - } & \text { Light Scattering } \\
\text { - } & \text { Diffraction }\end{array}$ & $\begin{array}{ll}\text { - } & \text { Polarization } \\
\text { - } & \text { Lasers } \\
\text { - } & \text { Rayleigh's Criterion }\end{array}$ \\
\hline
\end{tabular}

Table 3. PHOTON2 Course Topics and Laboratory Experiments

The course was designed in a way that would facilitate a high degree of collaboration intended to give participants an opportunity to work both independently as well as with their alliance members. This approach was based on research that shows that learning is maximized when learners draw upon the collective knowledge and experience of a community of learners [1, 6, $7,13,20]$. WebCT ${ }^{\circledR}$ was used as the delivery platform and the Internet was used extensively to supplement the course material. Each of the two cohorts was team-taught by highly experienced photonics educators partnered with adult learning experts. Coursework focused specifically on the development of content knowledge within the context of curriculum development and classroom applications. While the overall goal of helping teachers and faculty build a well-organized knowledge base in photonics technology and the ability to apply their new knowledge to develop and implement more effective instructional practices at the both classroom and the program level remained consistent for both Cohort 1 and 2, the approach taken was markedly different. In the following paragraphs, we describe the two different approaches and their effect on learning outcomes.

\section{B. Cohort 1}

The web-based learning model applied in the delivery of the Introduction to Optics and Photonics course for Cohort 1 was based on a traditional highly structured instructor-led format as illustrated in Figure 3. This approach was used as a result of demographic surveys that indicated most participants had never taken a web-based course. The concern was that in the 
absence of a structured learning environment typical of traditional face-to-face courses, learners who were new to web-based learning might not possess the self-directed learning skills needed to successfully navigate the course. This would lead to a feeling of isolation and potential disengagement from the learning process. By providing scaffolds for learning early on, the expectation was that as learners progressed through the course, the level of course structure would shift from a low autonomy mode (highly structured) to high autonomy mode (low structure) whereby over time, learners would assume an increasing level of responsibility for their own learning $[8,9,26,27,28]$. By the end of the 16 -week course, participants should have acquired the knowledge and skills needed to self-direct their own learning.

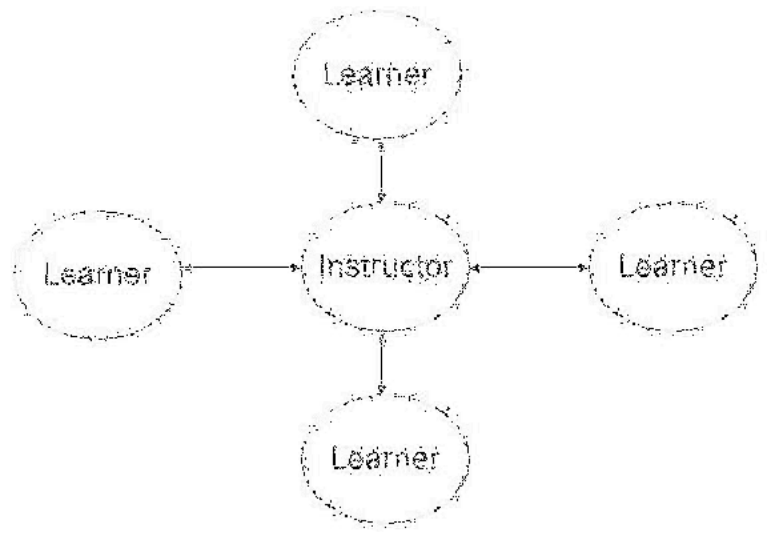

Figure 3. Instructor-Centered Course Format

Photonics concepts were presented in a highly structured format that allowed for individual and group problem solving, hands-on laboratory experiments with video demonstrations, web-based simulations, and online threaded discussions. Weekly reading and problem solving assignments for the entire semester were posted in the WebCT course site with clear explanations regarding expectations and performance. Content material was presented in a modular format with clearly delineated learning outcomes and timelines. Online self-assessments (self-tests) with constructive feedback were built into to course to aid participants in planning, monitoring, and evaluating their learning progress.

Participants were required to contribute at least two postings per week on topics related to course content, hands-on activities, and curriculum development. Participants were strongly encouraged to interact with their peers by replying to postings and sharing plans for implementation. To elicit and encourage critical thinking in threaded discussion postings, learners were given an online guide consisting of six strategies for improving critical thinking (i.e., link, reflect, analyze, build, offer, and engage) to be applied to responses before posting to an online discussion. Participants were also required the submit three reflective letters assigned in weeks 2, 9, and 15 of the course whereby participants were asked specific questions regarding their efforts in establishing learning goals, planning, monitoring, and evaluating their performance, and setting goals and objectives for the curriculum-building project to scaffold the 
development of self-regulation skills. A sample curriculum outline for a 3-week period is given below in Table 4.

\begin{tabular}{|c|c|c|c|}
\hline Activity & $\begin{array}{l}\text { Week } 7 \\
\text { Topic: Thin Films }\end{array}$ & $\begin{array}{l}\text { Week } 8 \\
\text { Topic: Diffraction }\end{array}$ & $\begin{array}{l}\text { Week } 9 \\
\text { Topic: Polarization }\end{array}$ \\
\hline $\begin{array}{l}\text { Learning } \\
\text { Goals Upon } \\
\text { completion of } \\
\text { this section } \\
\text { you will be } \\
\text { able to: }\end{array}$ & 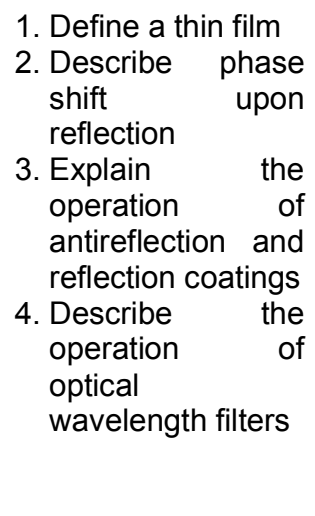 & $\begin{array}{l}\text { 1. Describe the } \\
\text { difference } \\
\text { between near field } \\
\text { and far field } \\
\text { diffraction } \\
\text { 2. Explain } \\
\text { Huygen-Fresnel the } \\
\text { principle } \\
\text { diffraction } \\
\text { 3. Use the single slit } \\
\text { diffraction } \\
\text { equation to solve } \\
\text { for slit width } \\
\text { and/or wavelength }\end{array}$ & $\begin{array}{l}\text { 1. Describe the difference } \\
\text { between random, plane, } \\
\text { circular, and elliptical } \\
\text { polarization } \\
\text { 2. Describe the creation and } \\
\text { modification of polarized } \\
\text { light: absorption, } \\
\text { reflection, scattering, and } \\
\text { birefringence } \\
\text { 3. Apply Malus law } \\
\text { 4. Explain and calculate } \\
\text { Brewster's angle }\end{array}$ \\
\hline Textbook & $\begin{array}{l}\text { 1. Chapter 5: End of } \\
\text { Chapter Problems } \\
\text { Part I. } \\
\text { 2. Web-based } \\
\text { application }\end{array}$ & $\begin{array}{l}\text { 1. Chapter 5: End of } \\
\text { Chapter Problems } \\
\text { Part II. } \\
\text { 2. Web-based } \\
\text { application }\end{array}$ & $\begin{array}{l}\text { 1. Chapter 6: End of Chapter } \\
\text { Problems } \\
\text { 2. Web-based application }\end{array}$ \\
\hline $\begin{array}{l}\text { Lab/ Hands- } \\
\text { on } \\
\text { Activity }\end{array}$ & The Air wedge & $\begin{array}{lr}\text { Single } & \text { Slit } \\
\text { Diffraction and/or } \\
\text { Diffraction by a } \\
\text { Hair }\end{array}$ & $\begin{array}{lll}\text { Malus } \quad \text { Law and/or } \\
\text { Brewster's Angle }\end{array}$ \\
\hline $\begin{array}{l}\text { Alliance/Gro } \\
\text { up } \\
\text { Discussion } \\
\text { Topics }\end{array}$ & 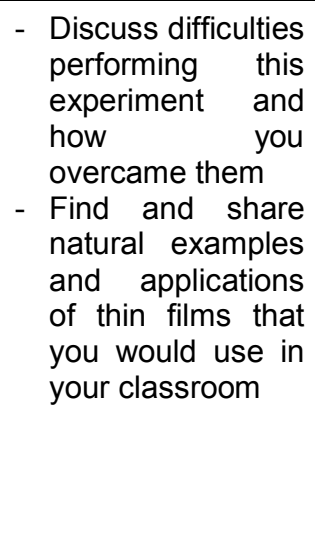 & $\begin{array}{l}\text { - Was this topic } \\
\text { presented at the } \\
\text { appropriate level } \\
\text { for your students? } \\
\text { - Which experiment } \\
\text { did you choose? } \\
\text { Why? } \\
\text { - Would you modify } \\
\text { this lab to better } \\
\text { suit your students? } \\
\text { If so, how? } \\
\text { - Find and share a } \\
\text { practical } \\
\text { application for } \\
\text { diffraction. }\end{array}$ & $\begin{array}{l}\text { - Was this topic presented at } \\
\text { the appropriate level for } \\
\text { your students? } \\
\text { - Which experiment did you } \\
\text { choose? Why? } \\
\text { - Would this lab be } \\
\text { appropriate for your } \\
\text { classroom? } \\
\text { - Find and share an } \\
\text { application of polarization. }\end{array}$ \\
\hline $\begin{array}{l}\text { Self- } \\
\text { Assessment }\end{array}$ & $\begin{array}{l}\text { Chapter } 5 \text { Online } \\
\text { Self-test }\end{array}$ & $\begin{array}{l}\text { Chapter } 5 \text { Online } \\
\text { Self-test }\end{array}$ & $\begin{array}{l}\text { Reflective Letter \& } \\
\text { Chapter } 6 \text { Online Self-test }\end{array}$ \\
\hline
\end{tabular}

Mise en forme : Puces et numéros

Table 4. Sample Three-Week Curriculum Outline 
Course expectations dictated that upon completion of each learning module, participants would work together to develop a detailed lesson plan, or curriculum map, for teaching their newly acquired photonics content knowledge in their own classrooms. Upon completion of the course, the culmination of these weekly curriculum-planning efforts would result in a comprehensive customized lesson plan for teaching photonics technology for each participant. To aid in the process, participant had access to a national network of industry mentors, photonics educators, and pedagogy experts committed to helping adapt content material to their own curricula.

\section{Research Findings for Cohort 1}

Research was conducted at the end of the Fall 2004 semester to examine the relationship between learner interaction, self-regulatory development, critical thinking skills, and learning outcomes. To better understand this relationship and to guide the implementation of the PHOTON2 web-based course for Cohort 2, the PHOTON2 research team addressed question: What is the nature of the relationship between learner interaction (i.e., learner-to-learner, learner-to-content, and learner-to-instructor), self-regulation, critical thinking, and learning outcomes in an online professional development course?

\section{Methods}

Quantitative and qualitative methods were used to address the research questions [7]. Data sources used in the study were demographic surveys, pre-post tests, threaded discussion text, reflective journals, and the Motivated Strategies for Learning Questionnaire (MSLQ) [29]. Demographic surveys were administered at the beginning of the course during the two-day introductory workshops. Pre- and post-content knowledge assessments (60-item, multiple choice questions; average alpha reliability of 0.840 computed using two trials) were administered online at the beginning (week 1) and end of the course (week 16). A threemember panel of photonics experts was used to ensure content validity. Threaded discussion data and reflective journal entries were compiled and open coded for the 16-week course to examine trends in learner interaction (learner-to-learner, learner-to-instructor, and learner-tocontent) and analyzed for evidence of critical thinking and self-regulatory development. Analysis of critical thinking involved coding and theming threaded discussion postings using six indicators (i.e., linking, reflecting, analyzing, building, offering, and engaging) [30]. Lastly, the selfregulation subscale of the MSLQ (18 items scored using a 7-point Likert scale; Mean values computed for the self-regulation subscale; average alpha reliability of 0.883 computed using two trials) was administered online during the second week and last week of the course to obtain pre-post measures of self-regulation.

\section{Results}

Of the 23 teachers who started the course for Cohort I, one withdrew for personal reasons and four changed to audit status because of situational constraints. Of the remaining 18 participants, complete data sets were obtained for 15 participants for analysis. All data were screen for outliers and normality. Analysis of data revealed the following:

Pre-post content knowledge: Results of paired t-tests showed a statistically significant increase $(t=-7.02, p<.001)$ in content knowledge. Based on comparisons with pre-post content knowledge scores recorded in previous classroom-based versions of the Introduction to Photonics courses, this result suggests that learning outcomes as measured by pre-post content knowledge in a web-based course in photonics 
technology are comparable to learning outcomes in traditional classroom instruction. Given that most participants had never taken a formal course in photonics, this result was no surprise. However, given the nature and difficulty often reported in teaching labbased technology courses online, this result was very encouraging.

Learner Interaction: In total, learners posted 681 messages over the 16-week period. Interaction was broken down into five categories, learner-to-all, learner-to-learner, learner-to-instructor, instructor-to-individual learner, and instructor-to-all. Analysis of threaded discussions showed a slight sequential increase in the level of learner interaction across all categories over the first three quarters of the semester and a dramatic drop in interaction during the fourth quarter of the course. This result is consistent with other research [30] in which researchers found similar patterns of participation in online courses. These results are shown in Figure 4.

One possible explanation for this drop in participation is that some learners may find it difficult to actively engage in a professional development activity for a prolonged period of time. Most professional development programs are usually offered as short-term workshops, which are not as demanding of time as a full semester web-based course. While the benefits of continuous learning are well documented, perhaps a compromise would be to break up the course into smaller more manageable "chunks", offered over a longer time frame.

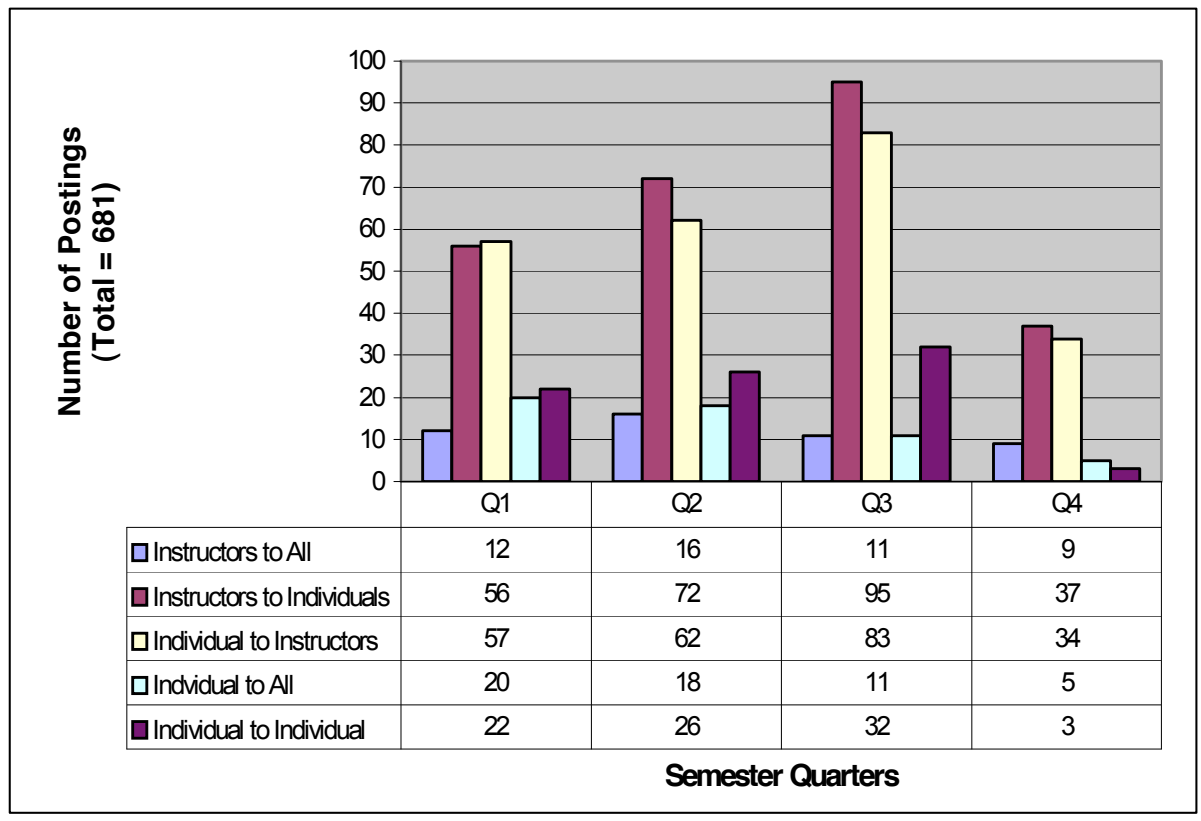

Figure 4. Online Interaction for Cohort 1 
While an increase in learner interaction was viewed as positive, most of the increases in interaction occurred between individuals and the instructor. We would like to have seen a higher level of learner-to-learner interaction, a cornerstone in collaborative learning. Analysis of threaded discussions showed that Cohort 1 participants were more likely to respond directly to the instructor's inquiries regarding technical content as opposed to engaging in online discourse with peers [7]. Overall, the majority of postings $(73 \%)$ most were between the instructors and individual learners. Throughout the semester, numerous attempts were made by the PHOTON2 instructors and adult learning experts to increase the level of learner-to-learner interaction in an effort to establish a more collaborative learning environment; participants did not respond accordingly - they were reluctant to "step outside the box." One of the most common reasons given for not participating in online interactions was lack of time due to full time teaching loads and other obligations such as family, committees, and other course work. While this may be true for many learners, it does not explain while some individuals can work around a busy schedule and fulfill their course obligations while others struggle to manage their time.

Another possible explanation for the lack of learner-to-learner interaction may have been due to the lack of social rapport between participants. While individuals within specific alliances did have an opportunity to meet face-to-face during the introductory two-day workshops and photographs of each participant were posted on the website, most of the participants had never met. Other researchers have reported similar findings, suggesting that before engaging in online instruction, instructors should spend more time upfront engaging in online social dialog to break down the social barriers that inhibit individuals from engaging in online discourse [7,31]. On the positive side, however, we did find that for those individuals who did post to regularly the threaded discussion board, a significant number of postings involved learners sharing their classroom experiences with other learners, which can be viewed not only as a measure of success in that PHOTON2 course content was being actively applied in the classroom, but also in the fact that learners were actually constructing knowledge in a collaborative manner.

Self-Regulation: Results of paired t-tests performed on the MSLQ self-regulation scale data showed a statistically significant increase $(t=-7.8, p<.001)$ in learner selfregulation. While no significant relationship was identified between learner interaction and self-regulation, or between learner interaction and learning outcomes, increases were found for levels of critical thinking. While speculative, this result suggest that the development of self-regulation skills may be more a function of the reflective activities required for critical thinking in threaded discussion postings and in the preparation of reflective letters than in the level of learner interaction. This result will be investigated further in subsequent research.

Critical Thinking: Evaluation of 140 postings was coded for levels and types of critical thinking. Initially the level of critical thinking was very low. The majority of the postings included comments such as "The topic is well-covered", "The content looks good", and " I did read through the lab and my first impression was that it seemed clear, informative, and easy to follow". This type of surface interaction was determined to be counterproductive to reaching the goal of active learning through collaboration. In an 
effort in increase the contribution of each participant, we introduced learners to six strategies for enhancing critical thinking (i.e. link, reflect, analyze, build, offer, and engage) to be applied to each posting to the online discussion. Facilitators replied by asking probing questions in response and modeled critical thinking in their postings. The result of making learners aware of critical thinking strategies was an increase in the quality of each participant's contributions to the online discussion. This was evident by the types of interactions between participants. Posting to the discussion now included such statements as "In my experience working at laser manufacturing companies..." "I would start the discussion on where parallel rays come from... It allows the student to easily estimate..." increased critical thinking, evident by the sharing of previous experience and curriculum implementation ideas enhanced the meaningful collaborative that results in higher learning outcomes.

\section{Cohort 2}

Based on these preliminary findings from Cohort 1, several changes were made to the PHOTON2 web-course. First, the 2-day regional introductory workshops were held closer in time to the beginning of the course (within 4-8 weeks) so that participants would not lose their momentum and motivation for taking the course nor their skill at navigating the course. Second, the course was opened for participation one week before the actual start date for the course so that participants could log on and introduce themselves to the larger group in an effort to increase the amount of social rapport. Participants were asked to discuss their educational background, where they were from, teaching environment, teaching philosophy, motivation for participating in the program, and any other information they wanted to share about their personal lives, hobbies, families, etc. Third, the scope of material to be covered during the semester was reduced. This change was based on a survey administered to Cohort 1 in which participants were asked to rate the importance of each topic covered ( 1 to 5 Likert scale) with regard to which topics were most likely to be taught in their classrooms. By reducing the amount of material covered, more time was able to be spent on core concepts with the hope of fostering deeper learning, and as a result, increase the likelihood that the material would (or could) be applied in their classrooms. Last, and most important, the format of the PHOTON2 web-based course was modified from a traditional instructor-centered format in which all course activities and discussions are centered on the instructor, to a learner-centered approach, where the role of the instructor shifts from leader to facilitator. The purpose for this change in format was to increase the level of learner-to-learner interaction in an effort to create a more collaborative learning environment where learners would work together to construct knowledge and ideas through interactions and responses from others [24]. A graphic illustrating the role of the instructor and learners is shown in Figure 5. 


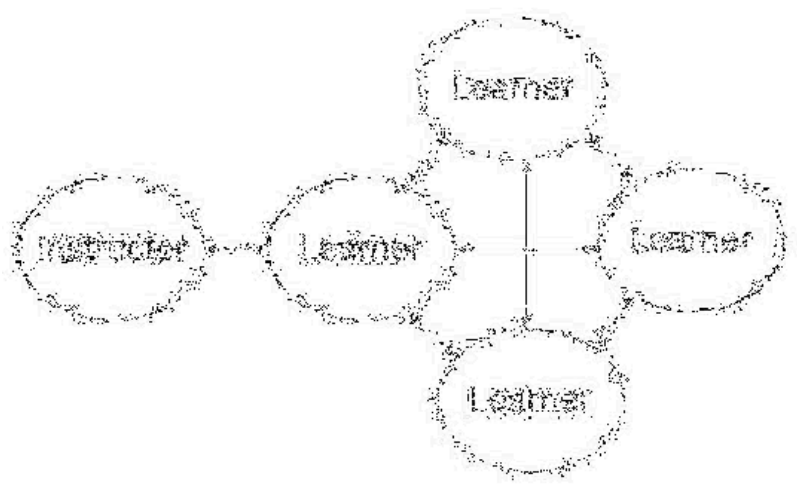

Figure 5. Learner-Centered Course Format

The web-based course for Cohort 2 was organized into two distinct activities, Learning Photonics and Teaching Photonics, which alternated throughout the semester as illustrated below in Figure 6. Participants were grouped together with their alliance members for the Learning Photonics segments and then grouped together with the same teaching level (e.g. high school and college teachers) for the Teaching Photonics segment, giving each participate the opportunity to collaborate with others with similar experiences and learning goals. 


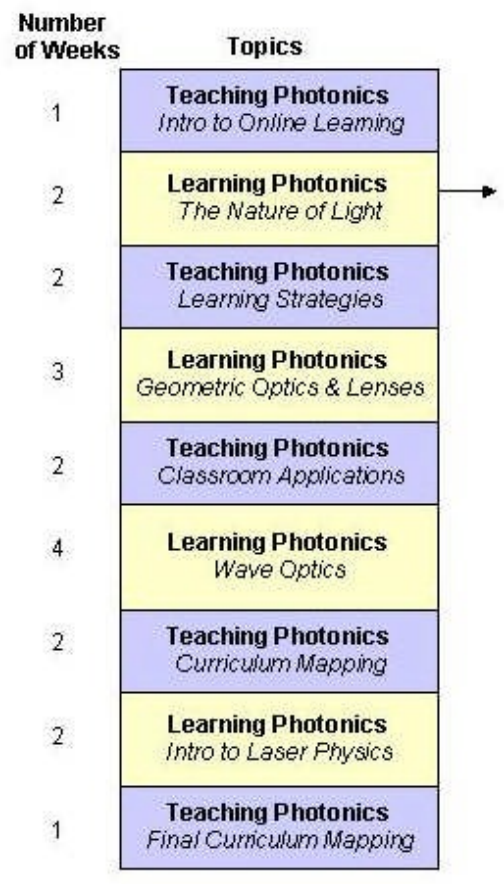

Sample Two-Week Period

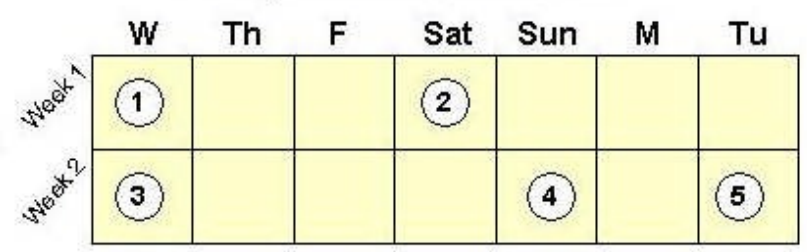

(1) Start of new topic: Instructor introduces new course material and group discussion topic. Participants perfom assigned reading and homework problems to establish knowledge base

(2) Group discussion begins: Group discussion leader initiates threaded discussion on assigned topic. Participants engage in group problem solving discussion. Instructor is available in the background to provide assistance if needed. Group discussion leader is selected by group.

(3) Instructor feedback: Group discussion continues. Instructor provides formal feedback to each group. Group uses feedback to synthesize and summarize problem solution.

(4) Group report due: Group discussion concludes with a formal report out of the problem solution. Instructor initiates open threaded discussion among all groups to compare an contrast individual group results.

(5) Instructor summary: Instructor summarizes group discussions and problem solution.

\section{Figure 6. Cohort 2 Web-Based Course Format}

Learning Photonics: In the Learning Photonics segment, learners were involved reading course material, engaging in individual and group problem solving, performing laboratory experiments, and applying their skills and knowledge in solving real-world problems. While the overall course requirements remained consistent with that of Cohort 1 , the format in which the course was organized was much different. Approximately every 2-4 weeks the instructor introduced a new photonics topic - typically on Wednesdays. Associated with each new topic was a thought provoking real-world problem related to that particular topic. Upon beginning a new topic, the learner would spend the first few days reading the assigned text, performing lab exercises, and working through the homework problems either individually or with their alliance members. Learners were encouraged to consciously think about the application problem while engaging in the course assignments. From Saturday to the following Tuesday, learners were instructed to engaged in a group discussion with their alliance to provide an opportunity to collaborate with their colleagues in solving the assigned application problem. Each alliance was instructed to select a discussion leader, who was responsible for leading the discussion group and reporting out the results of the problem solving session to the entire cohort for that particular segment. The role of discussion leader would alternate among alliance members of each Learning Photonics segment. This provided a forum for brainstorming and bouncing ideas off the others in the group. During this time the instructor was available on a limited basis to provide each 
alliance with critical feedback and insights. On the second Wednesday of the 2-week period, the instructor joined in the discussion to provide each group with more substantive feedback and help in synthesizing and summarizing the group's problem solution. On the second Sunday of the two-week period, each alliance group reported their problem solution to the entire cohort for open discussion facilitated by the instructor. Finally, on the last day of the two-week period (Tuesday), each group received a summary of the problem solutions presented by all of the alliances from the instructor to aid in the next Learning Photonics segment.

Teaching Photonics: Immediately following each Learning Photonics segment, participants engaged in online discussions that involved reflecting on what they have learned (and didn't learn), how they learned it, what strategies were most successful, and how best to implement what was learned in their own classroom. Following the same instructional format used in the Learning Photonics segment described above, learners participated in instructor-facilitated group discussions centered on (1) developing a curriculum implementation plan for teaching your own students, and (2) developing the metacognitive skills needed to engage in lifelong learning. In addition to participating in online group discussions, during each Teaching Photonics segment, each participant was also required to respond in his/her personal online reflective journal to a series of questions dealing with personal learning goals, learning strategies, curriculum development issues, and web-based learning issues. Unlike the Learning Photonics segment, discussion groups in the Teaching Photonics segment were organized according to grade level (i.e., high school or college) as opposed to regional alliances. This "cross-pollenization" of educational levels provided the opportunity for participants to collaborate with educators both regionally and nationally, and across educational levels.

\section{E. Research Findings for Cohort 2}

Using the same methods for data collection and analysis applied to Cohort 1, research was conducted at the end of the Spring 2005 semester with Cohort 2 to examine the relationship between learner interaction, self-regulatory development, critical thinking, and learning outcomes. The same research question was addressed for Cohort 2: What is the nature of the relationship between learner interaction (i.e., learner-to-learner, learner-to-content, and learnerto-instructor), self-regulation, critical thinking, and learning outcomes in an online professional development course? The only difference was in the pre-post content knowledge assessment instrument, which was modified to reflect the changes in course content (45-item multiple choice questions).

\section{Results}

Of the 28 teachers and faculty who started the course for Cohort 2, four withdrew for personal reasons within the first two week of the course and three changed to audit status because of situational constraint, and three not complete the course for other reasons. Of the remaining 18 participants, complete data sets were obtained for 13 participants for analysis. As in Cohort 1, all data were screened for outliers and normality. Analysis of data revealed the following:

Pre-post content knowledge: Results of paired t-tests showed a statistically significant increase $(t=-6.26, p<.001)$ in content knowledge. As in Cohort 1 , most participants had never taken a formal course in photonics, so it was expected that there would be a significant improvement in pre-post test performance. Again, given the nature and 
difficulty often reported in teaching lab-based technology courses online, this result was very encouraging as well.

Learner Interaction: In total, learners posted 445 messages over a 20 -week period. The additional 4-weeks for Cohort 2 was due to the additional week added at the beginning of the course to enhance social rapport and to orient participants with the web-based learning environment and three weeks added to the end of the semester to compensate for time lost during spring break for college and winter/spring break for high school. Interaction was broken down into five categories, learner-to-all, learner-to-learner, learner-to-instructor, instructor-to-individual learner, and instructor-to-all. As with Cohort 1 , analysis of threaded discussions showed a slight sequential increase in the level of learner interaction across all categories, but over two 4-week period rather than three, followed by a dramatic drop in interaction during the last three 4-week periods. Again, this result is consistent with other research [30] in which researchers found similar patterns of participation in online courses. These results are shown in Figure 7.

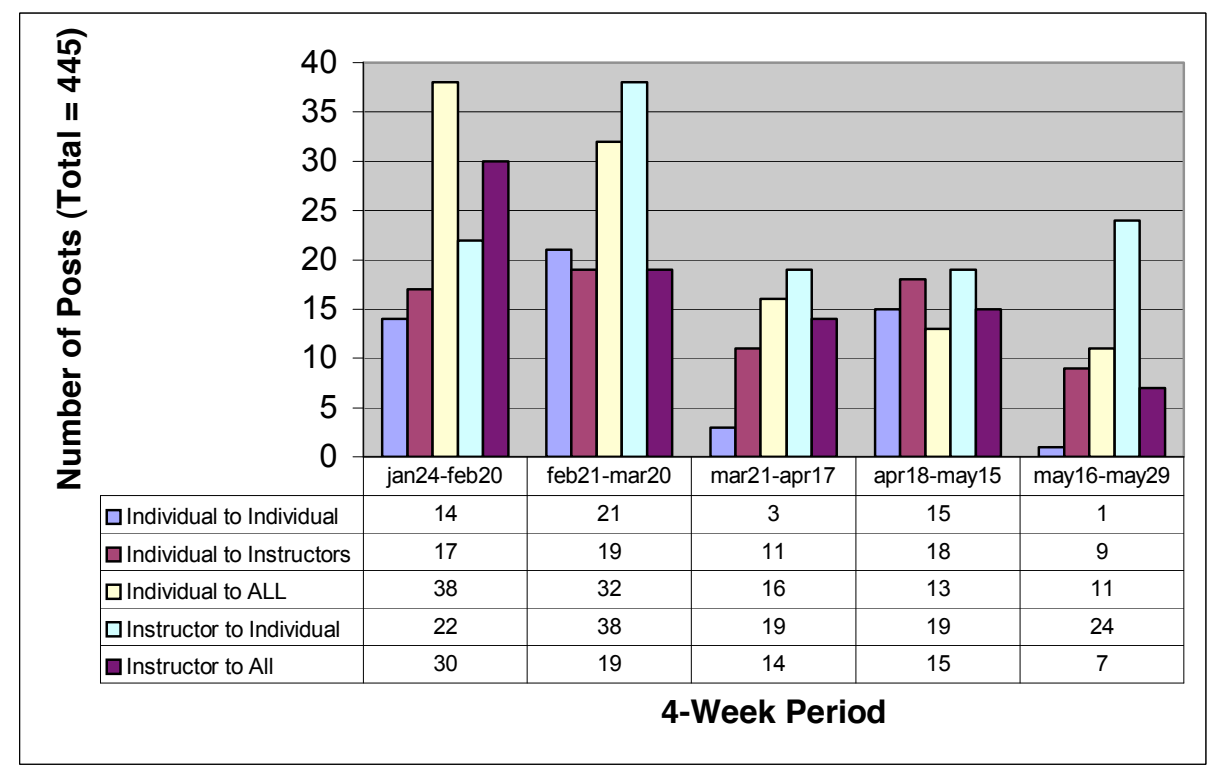

Figure 7. Online Interaction for Cohort 2

It should be noted that because participants were allowed to post to their personal reflective journals, which were not visible to the other participants in Cohort2, the total number of postings (445) does not include 76 private messages. This was not the case in Cohort 1, where all messages were visible. In addition, the relatively large number of posting from individual-to-all for the first 4-week period is the result of personal introductions that were posted globally. 
One interesting observation is that compared to Cohort 1 , the percentage of total postings between individual learners and the instructor in Cohort 2 went down from $75 \%$ to $43 \%$. At the same time, the percentage of total postings between for individuals increased from $20 \%$ to $36.9 \%$. This result reflects an increase in collaboration between participants of over $75 \%$, suggesting that the change in course format from instructorcentered to learner centered did in fact improve the level of peer-peer collaboration in the course.

While analyses of interaction data did show a marked increase in peer-to-peer collaboration as a percentage of total threaded discussion postings, analysis of threaded discussion data revealed that most learners were still dissatisfied with the level of interaction. Comments such as, "Now that we have started I'm getting a little concerned about the lack of participation by others. I would like to have the perspective of others to work off," and "I will try to create a routine so that I can keep up and regularly communicate with others...I do believe that working with others enhances learning and understanding" were echoed by many of the participants. Interestingly, while most participants viewed interaction with others as a very important part of online learning, many did not translate that sentiment into action - they "couldn't get past go" when it came to sitting down and posting a message.

One possible explanation may be that some learners lack the confidence or self-efficacy needed to translate thought into action. Research shows that in web-based learning situations, self-efficacy can mediate the relationship between metacognitive knowledge and self-regulation [8]. In other words, knowing what needs to be done (e.g., interacting) doesn't necessarily translate into doing what needs to be done (e.g., posting a message). Learners who lack the self-efficacy for interacting in an online environment, perhaps because their skill level is lower than others, or they do not feel they have anything positive to contribute, are often times at risk, likely to fall behind and eventually disengage from the learning process. The good news is that learners with low selfefficacy can build their confidence through the process of scaffolding, whereby an instructor or more knowledgeable peer helps the individual bridge the gap between participating and not participating by providing encouragement and support for their learning. Scaffolding is an inherent characteristic of collaborative learning - the greater the degree of collaboration, the greater the support network available to help learners develop the self-efficacy needed to self regulate their own learning $[1,7,9]$.

Self-Regulation: Results of paired t-tests performed on the MSLQ self-regulation scale data showed a statistically significant increase $(t=-5.218, p<.001)$ in learner selfregulation. While this result was comparable to the gains in self-regulation reported for Cohort 1 , which were attributed mainly to efforts used to encourage critical thinking in postings, improvements in self-regulation for Cohort 2 may also be attributed to the change in course format, which allowed for more time between main topics during the Teaching Photonics segment to respond to questions in the online reflective journal. In the reflective journal participants were asked to respond to questions pertaining to setting, monitoring and evaluating learning and implementation goals and performance, concerns and barriers with online learning and plans for overcoming them, and how 
interacting and collaborating with alliance and grade level groups enhanced their own learning. Threaded discussions in the Teaching Photonics segment focused on participants' expectations for working with their alliance group, how they would work together, and ways in which group discussions could maximize individual learning. Facilitators and participants experienced in online learning also provided support and strategies to help less experienced online learners become more effective. The format, structure, and discussion topics in the Teaching Photonics segment set the level of expectation for peer-to-peer interaction high, but provided the support, strategies, and encouragement necessary for the development self-regulation skills. This high level of participant support may have also contributed to an increase in learner self-efficacy, which has been linked to self-regulated learning $[1,7,9]$.

Critical Thinking: Participants were given the six strategies for enhancing critical thinking (i.e., link, reflect, analyze, build, offer, and engage) to apply in their threaded discussion postings during the two-day introductory workshop. Facilitators discussed the importance of applying critical thinking strategies in their threaded discussion postings and the effect on learning outcomes. Examples of each of the six strategies were discussed and participants practiced using these strategies in simulated threaded discussions during the two-day introductory workshop. These strategies were not covered in the introductory workshops for Cohort 1, but introduced later in the course as an intervention aimed at improving the quality of postings. Because of this early intervention for Cohort 2 as well as changes in course structure and reflective journal format, levels of critical thinking were higher much earlier in the course than in Cohort 1. Specifically, participants replied to threaded discussion questions in more detail, shared experiences and resources, and asked relevant questions to each other sooner rather than later as in Cohort 1.

\section{Observations, insights and recommendations}

Cohorts $1 \& 2$ provided some valuable insight into what works and what do not in a lab-based online professional development course. Qualitative and quantitative analysis of data as well as observations and insights gained through discussions and interviews with participants and instructors yielded the following recommendations:

1. Socialize - In an effort to increase learner-to-learner interaction, more time should be spent at the beginning of a web-based course prior to engagement in course content to establish social rapport amongst learners. Learners who are comfortable with the learning environment and feel that they are part of a supportive community of learners will be more likely to engage in online dialog and collaborative learning. Moreover, when students are explicitly encouraged by the instructors right at the start of the course to interact with peers and view peers as legitimate sources of information with experience, then they tend to more readily interact with each other online and also communicate with each other "behind the scenes."

2. Course Structure - The most common complaint from participants was the lack of time to perform course work, conduct lab experiments, work with alliance members on curriculum development, and participate in online threaded discussions. Interaction data for both cohorts showed a significant drop-off in participation after approximately 8 weeks. Based on this data, we recommend offering professional development in smaller more manageable 
"chunks" (e.g., 6-8 weeks) spread out over a longer period of time (e.g., two semesters rather than one) with ongoing technical support and mentoring. Separate out and conduct curriculum development and reflective activities in the interim period between "chunks." While coherent learning should always be one of the cornerstones of adult professional development, structuring learning activities in a way that provide learners with some "down time" to reflect on and experiment with what they have learned and how they learned it will help in making better decisions on how to implement curricula that will yield more positive results.

3. Clarify Expectations - Make clear expectations for course participation before beginning the course. Some of the comments made by Cohort 1 participants were that they "did not expect the course to take up so much time." The reality is that most web-based courses take at least as much time as classroom courses, if not more time [32]. While the benefits of access, convenience and opportunity for collaboration are well documented, the responsibility of completing course requirements still falls on the learner. By clarifying expectations such as time commitment, deadlines, rules for engaging in online discussions, and level of participation, learners can better plan for the amount of work required for successful completion of web-based courses.

4. Critical Thinking - At the beginning of the course, encourage critical thinking in threaded discussion postings by providing learners with an online guide or template consisting of strategies for improving critical thinking (i.e., link, reflect, analyze, build, offer, and engage) to be applied before posting to an online discussion. Applying this strategy will promote more substantive and thoughtful contributions to the online discussion and may foster the development of self-regulation skills critical to lifelong learning.

5. Use Video - Provide supplementary video (e.g., VHS, CD-ROM, MPEG, etc) to clarify concepts and/or experiments. The majority of participants from both cohorts indicated that the CD-ROM videos of laboratory exercises were extremely valuable in helping not only to identify unfamiliar laboratory components, but also to demonstrate more complex procedures and experimental set-ups. The use of video also adds a human element to an otherwise isolated learning format.

6. Scaffold Self-Regulation - Quickly identify "at risk" learners who may lack the self-regulation skills necessary for successfully participating in a collaborative online course. These learners can be identified as those that start out with enthusiasm and quickly drop off in their level of participation in threaded discussions. Provide these participants with additional support in developing and using self-regulation strategies needed to plan, monitor and evaluate their learning strategies. This should result in a higher level of participation and more positive learning outcomes.

\section{Conclusion}

The goal of Project PHOTON2 was to increase the number of high school teachers and college faculty across the US prepared to teach photonics technology at their own institutions through the development and implementation of a web-based professional development model grounded in adult learning principles. Through participation in the three-year project, participants will (1) develop core competency in optics and photonics technology; (2) apply and adapt optics and photonics content into their own courses and curriculum; (3) develop the self-directed learning skills critical to life-long learning; and (4) establish and maintain a collaborative online learning community consisting of peers, mentors, and industry professionals that support the transfer of learning through synergistic learning activities. The pedagogical framework 
integrated active, continuous, coherent, collaborative, and self-regulated learning elements into an online learning environment in which learners actively engaged in individual and group problem-solving and hands-on laboratory experiences, scaffolding of self-regulated learning strategies, and collaboration with other educators both locally and nationally on issues of curriculum development and implementation.

The PHOTON2 project also sought to answer research questions regarding the viability of webbased professional development, specifically: What is the nature of the relationship between learner interaction (i.e., learner-to-learner, learner-to-content, and learner-to-instructor), selfregulation, critical thinking, and learning outcomes in an online professional development course. Pre-post test scores for two cohort groups were comparable with pre-post content knowledge scores recorded in previous classroom-based versions of the same course (Introduction to Optics and Photonic), suggesting that learning outcomes in an online laboratorybased course in photonics technology are comparable to learning outcomes in traditional classroom/laboratory instruction.

Course structure was found to impact both the types and level of interaction between participants. Cohort 1 was taught using an instructor-led format, Cohort2 a learner-centered format. Other differences included the manner and timing in which content and curriculum development activities were addressed. Results showed that overall, the level and quality of collaboration among learners was greater in Cohort 2, suggesting that the learner-centered course format allowed for more social interaction and also yielded a higher level of critical thinking among learners. Results also showed that the number of postings to the threaded discussions declined in that second half of each cohort group. This finding was comparable to other findings of other studies, suggesting that a reduction in the traditional length of courses (e.g., from 16-weeks to 8-weeks) may be necessary to accommodate the hectic schedules of adult learners. Further research is necessary to identify other contributing factors to this reoccurring phenomenon.

Self-regulation skills significantly increased in both cohort groups. This result suggests that the development of self-regulation skills may be a function of the reflective activities required for critical thinking in threaded discussion postings and in the preparation of reflective journals. While self-regulation skills did improve in both cohorts, there was little evidence to suggest a direct relationship between self-regulation and learner interaction. As a result, more research is needed to examine this relationship. Results also suggested that the level of critical thinking in threaded discussion postings was the result of clearly delineated strategies for incorporating critical thinking into online threaded discussion postings and facilitator feedback modeling the use of these strategies. When participants were made aware of specific strategies for incorporating critical thinking indicators into their postings at the beginning of the course and facilitators ask probing questions to model critical thinking in their response to participants' postings, the level of critical thinking increased.

Based on our findings, recommendations were made to enhance learning outcomes in webbased professional development. Specifically, facilitators should design web-based courses to allow for increased social interaction prior to beginning a course; structure courses to allow for more time to engage in reflective activities and online social dialog; provide learners with clear expectations for course performance; group participants into learning groups with similar 
interests and backgrounds; identify early on those participants who may lack the self-regulation skills needed to succeed and provide scaffolds to facilitate the development of those skills; and provide strategies and examples for incorporating critical thinking in online discussion postings.

\section{Acknowledgements}

Project PHOTON: A Curriculum Development, Teacher Enhancement and Laboratory Development Project

Funded in part by the Advanced Technological Education program of the National Science Foundation (ATE \#ATE 0053284). Principal Investigator, Judith Donnelly, Three Rivers Community College; Co-Principal Investigators Fenna Hanes (Project Manager), New England Board of Higher Education; John Swienton, Exfo USA, Inc.; Senior Personnel Nicholas Massa and Barbara Washburn, both Springfield Technical Community College

\section{Project PHOTON2: Web-based Collaborative Learning for Teachers}

Funded in part by the Advanced Technological Education program of the National Science Foundation (ATE \#ATE 0302528). Principal Investigator, Fenna Hanes (Project Manager), New England Board of Higher Education; Co-Principle Investigators, Judith Donnelly, Three Rivers Community College; Marijke Kehrhahn, Neag School of Education (University of Connecticut); Nicholas Massa and Barbara Washburn, both Springfield Technical Community College

The authors wish to thank Dr. Marijke Kehrhahn and Dr. Barry Sheckley from the University of Connecticut Neag School of Education for their invaluable contributions and support to Project PHOTON2.

\section{References}

[1] Massa, N. M., Kehrhahn, M., Donnelly, J., Hanes, F., \& Washburn, B. A., "PHOTON2: A Web-Based Professional Development Model In Photonics Technology Education," Paper presented at the SPIE Annual Conference, Ottawa, Canada, September 2004.

[2] Harnessing Light: Optical Science and Engineering for the 21st Century, National Academy Press Washington DC, 1998.

[3] Massa, N. M., Donnelly, J., Hanes, F., \& Washburn, B. A., "The Light Fantastic: PHOTON Materials For Technician Education," Paper presented at the Optical Society of America (OSA) Education and Training in Optics and Photonics (ETOP) Annual Conference, Tucson, AZ, 2003.

[4] Hartley, K., \& Bendixen, K., "Educational Research In The Internet Age: Examining The Role of Individual Characteristics," Educational Researcher, 30(9), 22-26, 2001.

[5] Gallagher, R., "The next 20 years: How is Online Distance Learning Likely to Evolve?" 2003 UCEA 88th Annual Conference: March 28-30, Chicago, Illinois, 2003.

[6] Collison, G., Elbaum, B., Haavind, S. \& Tinker, R., Facilitating Online Learning: Effective Strategies for Moderators, Madison, WI: Atwood Publishing, 2000.

[7] Massa, N.M., Vallieres, K. M., Kehrhahn, M., \& Bell, A., "Learner Interaction and SelfRegulation in Web-Based Professional Development," Paper presented at the ASEE Annual Conference, Portland Oregon, June 2005. 
[8] Massa, N. M., "Metacognition and Persistence in Web-Based Courses," Doctoral Dissertation, University of Connecticut, Storrs, CT, 2003.

[9] Cennamo, K. S., Ross, J. D., \& Rogers, C. S., "Evolution of a Web-Based Course: Incorporating Strategies for Self-Regulation," Educause Quarterly, 25(1), 28-33, 2002.

[10] Hase, S. \& Ellis, A., "Problems with Online Learning are Systemic, not Technical," In Stephenson, J. (Ed). Teaching And Learning Online: Pedagogies for New Technologies. Kogan Page: Sterling, VA, pp. 27-34, 2001.

[11] Roblyer, M.D., \& Wiencke, W.R., "Design and Use of a Rubric to Assess and Encourage Interactive Qualities in Distance Courses," The American Journal of Distance Education, 17(2), 77-98, 2001.

[12] Aviv, R., "Educational performance of ALN via content analysis," Retrieved June 16, 2003 from http://www.aln.org/alnweb/journal/Vol14 issue2?le/reuven?LE-reuven.htm

[13] Byers, A., "Interaction: The Key to Successful Distance Learning," Paper presented at EdMedia 2000: World Conference on Educational Multimedia, Hypermedia and Telecommunications, Montreal, Canada, 2000.

[14] Caffarella, R.S., Planning Programs for Adult Learners: A Practical Guide for Educators, Trainers, and Staff Developers, Jossey-Bass Publishers, San Francisco, 1994.

[15] Knowles, M.S., “Andragogy, not Pedagogy," Adult Leadership, 16,10, pp. 350-352, 386, 1980.

[16] Brookfield, S., Understanding and Facilitating Adult Learning, Jossey-Bass Publishers, San Francisco, 1986.

[17] Cross, K.P., Adults as Learners, Jossey-Bass Publishers, San Francisco, 1981.

[18] Jarvis, P., Adult and Continuing Education, Croom Helm Publishers, London, 1987.

[19] Knox, A. B., "Proficiency Theory of Adult Learning", Contemporary Educational Psychology, 5, pp. 378-404, 1980.

[20] Keeton, M. T., Sheckley, B. G., \& Griggs, J. K., Effectiveness and Efficiency in Higher Education for Adults, Council for Adult and Experiential Learning (CAEL), Chicago, 2002.

[21] Corcoran, T. B., "Transforming Professional Development for Teachers: A Guide for State Policymakers," National Governors' Association, Washington, DC, 1995.

[22] Harasim, L., "Teaching by Computer Conferencing," In A. Miller (Ed.), Applications of computer conferencing to teacher education and human resource, 1990.

[23] Hiltz, S.R., The Virtual Classroom: Learning without Limits via Computer Networks. Norwood, NJ: Ablex Publishing Corporation, 1994.

[24] Hiltz, S. R., "Collaborative Learning in Asynchronous Learning networks: Building Learning Communities," In: WebNet 98 World Conference of the WWW, Internet and Intranet Proceedings, Orlando, FL. ERIC Clearinghouse on Higher Education, 1998. ERIC, ED427705

[25] Johnson, D. W., "Student-Student Interaction: The Neglected Variable in Education," Educational Research, 10(1), 5-10, 1981. 
[26] Grow, G. O., "Teaching Learners to be Self-Directed." Adult Education Quarterly, 41 (3), 125-149, 1991.

[27] McLaughlin, M. W., \& Oberman, I., Teacher Learning: New Policies, New Practices, Teachers College Press, New York, 1996

[28] McMahon, M., "Designing an Online Environment to Scaffold Cognitive Self-Regulation," [Online] 2002.

http://www.ecu.edu.au/conferences/herdsa/papers/ref/pdf/McMahon.pdf.

Available:

[29] Pintrich P., Smith D., Garcia T., \& McKeachie W., "A Manual for the Use of the Motivated Strategies for Learning Questionnaire," Technical Report 91-B-004. The Regents of The University of Michigan. 1991.

[30] Bell, Kehrhahn, James, \& Vincent -Pending Publication.

[31] Molinari, D. L., "The Role of Social Comments in Online Problem-Solving Groups," The American Journal of Distance Education, 18(2), 2004 2000

[32] Sheckley, B. G., "Summary of Time Study Data Analysis," Unpublished manuscript, 